\title{
Educational Problems of Teacher trainees studying in District Institute of Education and Training (DIETs)
}

\author{
Sukanta Kumar Pradhan
}

Assistant Professor in Education, Indira Gandhi Govt College, Tezu, Arunachal Pradesh, India

Corresponding author: drsukantaorissa@gmail.com

\author{
Received: 08-04-2020 \\ Revised: 20-06-2020 \\ Accepted: 25-07-2020
}

\begin{abstract}
Since the very dawn of the human civilization, teacher occupied a pivotal place in the spectrum of education. A teacher is a nation-builder, social architect and torch- bearer of a society. Teaching profession is considered to be one of the noblest professions. The term in-service teacher education or continuing education in a broad sense includes all experiences and activities provided to the teachers and designed to promote personal and professional growth. The District Institute of Education and Training (DIETS) were first established on the recommendations of the National Policy on Education (NPE) 1986 for imparting training to the teachers at Elementary level. The Present study was undertaken to study the educational problems of DIET trainees and to evolve insights and mechanisms to mitigate these problems.
\end{abstract}

Keywords: DIETS, Teaching Profession, Educational Problems

Since the very dawn of the human civilization, teacher occupied a pivotal place in the spectrum of education. A teacher is a nation-builder, social architect and torch- bearer of a society. Teaching profession is considered to be one of the noblest professions. Traditionally a person by dint of his devotion and deep contemplation joined the teaching profession. However, in due course of time and advancement of civilization now people join the teaching profession mostly by compulsion not by passion because of some or other reasons. Hence, this changing attitude and perception towards teaching profession needs careful analysis and examination.

Teaching as a profession implies that people who have joined teaching, he should take it as a vocation that he has the aptitude of teaching. Teaching skills can be developed with the help of feedback devices. It involves more than job skills and aptitude of teaching. There are some ethical considerations and social responsibility. The person's attitude and behavior should be an ideal person of a society as his students follow or imitate the teacher. Hence, teaching profession and the roles and responsibilities of the teacher are highly appreciated in each society.

The importance of teachers cannot be overemphasized because the strength and success of an educational system depends on them whether they teach in the schools, colleges or universities. Actually, the quality of a nation depends on the quality of its citizen depend on the quality of their education. A teacher's personal qualities, educational qualification, his professional training, his attitude towards teaching professional, his job satisfaction, managerial skill etc help him to contribute considerably towards the development of the society. However, teaching as a profession consists of teaching attitude, aptitude, skills and other social accountability at large.

Now a day's teacher's professional development is an important issue in the areas of teacher-

How to cite this article: Pradhan, S.K. (2020). Educational Problems of Teacher trainees studying in District Institute of Education and Training (DIETs). Educational Quest: An Int. J. Edu. Appl. Soc. Sci., 11(2): 113-119. Source of Support: None; Conflict of Interest: None (क) क्ष 
education. It is stated in several ways. There should be professionalization of teaching at every level i.e. from primary stage to the higher education. Teachers should develop his professional excellence. There are some fundamental questions related to professional development such as what is teaching profession? How is it different from other professions? Up to what extent teaching can be accepted as profession? What are the ways and means for professional development? How can professional development be measured? These questions have answered in this chapter for the awareness of this issue.

Teaching as profession consists of teaching aptitude, teaching skill and social responsibility programme. These factors should be included and awareness can be provided about the teaching profession. The importance of quality of teacher cannot be overemphasized because the strength and success of an educational system depends on them weather they teach in schools, colleges or universities. Actually, the quality of a nation depends on the quality of its citizens depends on the quality of their education. The quality of their education reflects, more than any other single factor, the quality of their teachers. A teacher's personal qualities, educational qualification, his professional training, high managerial skills and the place he occupies in the college and in the community contributes to the quality of his teaching. The education of a teacher is not complete on receiving a degree or diploma from a college or university. Pre-service education or joining a college or university department is only the first stage in the continuous growth of a teacher in his profession. In the words of Rabindranath Tagore, 'a teacher can never truly teach unless he is still learning himself. A lamp can never light another lamp unless it continuous to burn its own flame.'

The education of a teacher is never complete. The teacher never prepared for his profession before he enters it, but he must also be prepared again and again to keep abreast with latest developments. To satisfy this need is the purpose of in-service / continuing education. Every teacher, weather he is a beginner or a vocation, needs to be aware of the rapid cultural and social change, advancement in educational theories, methodologies and practices, increase in student enrolment and range in the interest and abilities of students and the ramification of the role of education due to change and advancement of science and technology. The frontiers of human knowledge in various fields expand rapidly. There is a need for continued study and growth that would raise the competence of a teacher on job in turn increase the standard of the whole educational system.

The term in-service teacher education or continuing education in a broad sense included all experiences and activities provided for teachers and designed to promote personal and professional growth. The continuing education also has the connotation of the life-long education; of educating oneself throughout life, whether he is a student, teacher or a non-professional.

The Programme of Action of National Policy on Education (1986) has indicated that the needs for in-service education of teachers arise from several sources such as changing national goals, revisions of curricula of schools and colleges, additional inputs in the teaching learning system, inadequate background of teachers etc. Hence, care should be taken to see that some of the courses mentioned and the corresponding needs that arise from these sources are reflected in the in-service programmes.

\section{District Institute of Education and Training: Its Inception and Importance}

Teacher education can be classified under two groups such as pre-service teacher education and in-service teacher education. Accordingly, teacher training institutions are also categorized into two types like pre service teacher education institutions and in service teacher education institutions. Some teacher training institutions provides both pre-service and in-service training to the teachers. There are several teacher training institutions such as the Institute of Advanced Studies in Education (IASEs), Colleges of Teacher Education (CTEs), Secondary Training Schools (STS), District Institute of Education and Training (DIETs) etc. Further, several institutions like the IGNOU, New Delhi, Academic Staff Colleges (ASCs) presently HRDCs, NCERT and SCERTs provide short term in service training programmes to the teachers for their professional growth and development. Hence, all the teacher education institutions are regulated, recognized and controlled by an apex body, the National Council for Teacher Education (NCTE), 
New Delhi which is a statutory organization of the government of India.

The District Institute of Education and Training (DIETS) were first established on the recommendations of the National Policy on Education (NPE) 1986. Accordingly, in each district a DIET was established throughout India and also in Arunachal Pradesh. The first DIET centre of the state of Arunachal Pradesh was established in the year 1988 at Changlang as per the recommendations of the NPE (1986). Previously it was the state institute of Education (SIE), Changlang. At present the number of DIETs is increased up to 11 in the state of Arunachal Pradesh. The DIETs are run by the Directorate of School Education, Govt. of Arunachal Pradesh and offer a two year Diploma in Elementary Education (D.El. Ed) course. Besides, the DIETs are also providing short term in-service training to adult, non-formal and SSA teachers from time to time. The curriculum of the DIETs are so designed that the trainees acquire both theoretical and practical knowledge.

Nevertheless the trainees of these DIETs at present pursue the course in order to get into the teaching profession. However, they fail to understand the values, norms and professional ethics of the teaching profession. The teacher is the backbone of the educational system, maker of the mankind and architect of the society. But the status of the teachers deteriorated over the last few decades mainly due to poor service conditions, lowering standard of teacher education, changes in the value system, inability to understand the professional ethics by the teachers and poor attitude of the teachers towards teaching profession. Moreover, they have varied level of problems related to curricular and extracurricular programmes, problems of education and training at the DIET and at their hostel and home environment, problem related to motivation on the part of the teachers etc.. .Hence, it is essential to study the educational problems of the DIET students so that the causes of problems can be found out and accordingly necessary steps can be taken.

\section{Educational Problems of DIET Trainees}

The students of DIETs undergo pre-service training course D.El. Ed. (Dip. in Elementary Education. The students face several problems during the course of training both at the institution and at their residences. Some students face the problem of adjustment because of the change in the environment and change in the structure and peer group. Some other students face peculiar problems like fear psychosis towards the new course, inferiority complex and lack of intrinsic motivation. Quite contrary some other students have problems related to the course itself because of change in stream, teachers attitude, lack of clarity in perception of teaching profession and problems arising out of the process of organization of curricular and cocurricular activities.

Looking into the above discussed problems of DIET students the researcher has undertaken the present study on the DIET students of DIET, Kamki West Siang district of Arunachal Pradesh.

\section{Brief Outline of the study area DIET, KAMKI}

The DIET, Kamki was started as District Resouce Centre (DRC) in the year 2003 at Kamki. It was upgraded into DIET in the year 2012 by the state government of Arunachal Pradesh. The DIET, Kamki is functioning as a full-fledged teacher education institution offering DEd course to the students. It is also providing Dl.Ed course and in-service training under IGNOU, New Delhi. The institution meets the training needs of West Siang district in particular and helps in providing training and other skill development programmes. For the present study the investigator selected the DIET, Kamki as it will be convenient for data collection and to bring improvement on the basis of the findings.

\section{Rationale of the study}

Education is a continuous process of bringing an all round development of personality of the students in the educational institutions. It is a powerful instrument of social change and human resources development only when they are educated properly. The task of educating the human resources is on the teachers. Hence, teachers are torch bearers and nation builders. The Kothari Commission (1964-66) emphatically started that "The destiny of India is being shaped in its classroom". This statement signifies that teachers are the social architects and engineers. The development, progress and prosperity of a nation depend on resourceful, skillful and competent teachers. 
All philosophical doctrines like idealism, pragmatism, realism, existentialism etc also give prominent place to the teachers. Besides, all great philosophers of the west and the east like Dewey, Gandhi, and Vivekananda etc laid emphasis on the role of the teacher in their philosophy of education. Hence, at the modern context, a teacher is required to acquire adequate knowledge, skills, interests and positive attitude towards the teaching profession. The teacher's work has become more complicated and technical in view of new theories of psychology, philosophy and pedagogy and the emergence of Information Communication Technology (ICT). Hence, the NCTE, New Delhi is taking several measures to make teaching profession a noble and intellectual profession by initiating several measures such as curricular reconstruction, introducing new modules and new pedagogy in teaching. Nevertheless the trainees of these DIETs at present pursue the course in order to get into the teaching profession. However, they fail to understand the values, norms and professional ethics of the teaching profession. During this training period they face numerous problems related to their course of study, study atmosphere, organizational climate of the institution, their teachers and their methodology of teaching etc. Hence, it is essential to study the problems of education of the DIET trainees so that the reasons of their educational problems can be found out and necessary solutions and measures can be evolved.

\section{Statement of the Problem}

The research problem of the present study was stated as "Educational Problems of teacher trainees studying in District Institute of Education and Training (DIETs)".

\section{Objectives of the study}

The following were the objectives of the study:

(i) To study critically the educational problems of DIET trainees in relation to different factors.

(ii) To workout the implications of the study on educational problems for planning and designing appropriate educational ventures for the DIET trainees.

\section{Operational definitions}

Educational Problems: it refers to the problems that the DIET students are supposed to face during their course of study.

DIET Students: the students studying in DEd Course at District Institute of Education and Training, Kamki in the present study.

\section{Methodology and Design}

The present research study was a normative survey method under the descriptive research.

\section{Population of the study}

The total population of the present study covered 120 students studying in the DIET, Kamki in the west siang district of Arunachal Pradesh.

\section{Selection of sample}

The sample for the present study consisted of 50 DIET students selected from DIET, Kamki in west siang District of Arunachal Pradesh. The investigator selected the sample for the present study on the basis of simple random sampling procedure .

\section{Tools and Techniques used}

The following tool was used for collection of relevant data:

1. Self-developed questionnaire on Educational Problems for the DIET Trainees.

\section{Process of data collection}

Relevant data were collected from the teacher trainees by personally visiting the DIET, Kamki campus before the lockdown in the month of November 2019.

\section{Scope and Delimitations of the study}

The scope of the present study was limited to 50 DIET trainees of DIET, Kamki and one selfdeveloped questionnaire on Educational Problems.

\section{Analysis and Interpretation of Data}

The investigator used appropriate statistical techniques feasible for analysis and interpretation of data. The simple percentage analysis was used to analyze and interpret the data. 
Table 1: Discontinuance of studies

\begin{tabular}{lll}
\hline Did you ever your & \multicolumn{2}{c}{ DIET Students } \\
\cline { 2 - 3 } discontinue your studies? & Number & Percentage \\
\hline Yes & 02 & $4.00 \%$ \\
No & 48 & $96.00 \%$ \\
\hline
\end{tabular}

Table 2: Frequency of absence from the DIET

\begin{tabular}{lll}
\hline How frequently you remain & \multicolumn{2}{c}{ DIET Students } \\
\cline { 2 - 3 } absent from the DIET? & Number & Percentage \\
\hline Yes, frequently & 13 & $26.00 \%$ \\
Occasionally & 07 & $14.00 \%$ \\
Rarely & 30 & $60.00 \%$ \\
\hline
\end{tabular}

Table 3: Educational Aspiration of parents

\begin{tabular}{lll}
\hline In your opinion why do your & \multicolumn{2}{c}{ DIET students } \\
\cline { 2 - 3 } parents send you to the DIET. & Number & Percentage \\
\cline { 2 - 3 } $\begin{array}{l}\text { They consider it necessary to } \\
\text { educate you }\end{array}$ & 40 & $80.00 \%$ \\
$\begin{array}{l}\text { Other send their Children to } \\
\text { DIET }\end{array}$ & 00 & $0.00 \%$ \\
Not to allow you to be way ward & 10 & 20.00 \\
Can't say & 00 & $0.00 \%$ \\
\hline
\end{tabular}

Table 4: Difficulty in understanding the subjects taught

\begin{tabular}{lll}
\hline Do you have difficulty in & \multicolumn{2}{c}{ DIET Students } \\
\cline { 2 - 3 } understanding what & Number & Percentage \\
\hline No I do not have any difficulty & 30 & $60.00 \%$ \\
I have difficulty in few subjects & 15 & $30.00 \%$ \\
I have difficulty in most of the & 05 & $10.00 \%$ \\
subjects & & \\
\hline
\end{tabular}

Table 5: Reasons of Difficulty in Understanding

\begin{tabular}{lll}
\hline If you have difficulty, please point & \multicolumn{2}{c}{ DIET Students } \\
\cline { 2 - 3 } out the important reasons & Number & Percentage \\
\hline Harness of subject & 01 & $5.00 \%$ \\
$\begin{array}{l}\text { Inability of teachers to explain } \\
\text { properly }\end{array}$ & 05 & $25.00 \%$ \\
$\begin{array}{l}\text { Use of difficult language by the } \\
\text { teacher }\end{array}$ & 02 & $10.00 \%$ \\
$\begin{array}{l}\text { Lack of ability to follow studies } \\
\text { Lack of interest in studies }\end{array}$ & 00 & $0.00 \%$ \\
$\begin{array}{l}\text { Frequent illness } \\
\text { Irregular attendance in DIET }\end{array}$ & 00 & $0.00 \%$ \\
$\begin{array}{l}\text { Domestic engagements } \\
\text { Lack of quiet place for studies at }\end{array}$ & 06 & 0.00 \\
home & 03 & $30.00 \%$ \\
\hline
\end{tabular}

Table 6: Difficulty level of subjects

\begin{tabular}{lll}
\hline Which of the following & \multicolumn{2}{c}{ DIET Students } \\
\cline { 2 - 3 } subjects you find difficult & Number & Percentage \\
\hline English & 15 & $30.00 \%$ \\
Educational philosophy & 25 & $50.00 \%$ \\
Educational psychology & 05 & $10.00 \%$ \\
Health and hygiene & 01 & $2.00 \%$ \\
Geography & 02 & $4.00 \%$ \\
Hindi & 01 & $2.00 \%$ \\
Social Studies & 01 & $2.00 \%$ \\
\hline
\end{tabular}

Table 7: Availability of proper study atmosphere at home

\begin{tabular}{lll}
\hline Do you get proper study & \multicolumn{2}{c}{ DIET Students } \\
\cline { 2 - 3 } atmosphere at home? & Number & Percentage \\
\hline Yes & 30 & $60.00 \%$ \\
No & 20 & $40.00 \%$ \\
\hline
\end{tabular}

Table 8: Amount of time devoted for study

\begin{tabular}{lll}
\hline How much time do you devote & \multicolumn{2}{c}{ DIET Students } \\
\cline { 2 - 3 } to your studies at home? & Number & Percentage \\
\hline One hour & 00 & $0.00 \%$ \\
Two hours & 30 & $60.00 \%$ \\
Three hours & 15 & $30.00 \%$ \\
More than three hours & 05 & $10.00 \%$ \\
\hline
\end{tabular}

Table 9: Provision of Guidance and Advice from Teachers

\begin{tabular}{llc}
\hline Do your teachers provide Guidance & \multicolumn{2}{c}{ DIET Students } \\
\cline { 2 - 3 } and advice when you need? & Number Percentage \\
\hline Yes, quite often & 20 & $40.00 \%$ \\
Yes, some times & 27 & $54.00 \%$ \\
No, Never & 03 & $6.00 \%$ \\
\hline
\end{tabular}

Table 10: Participation in co-curricular activities

\begin{tabular}{lll}
\hline How frequently you have & \multicolumn{2}{c}{ DIET Students } \\
\cline { 2 - 3 } participated in co-curricular & Number & Percentage \\
\cline { 2 - 3 } activities of the college? & 25 & $50.00 \%$ \\
Frequently & 20 & $40.00 \%$ \\
Occasionally & 05 & $10.00 \%$ \\
Rarely &
\end{tabular}

Table 11: Educational Aspiration of DIET Students

\begin{tabular}{lll}
\hline Upto what level will you & \multicolumn{2}{c}{ DIET Students } \\
\cline { 2 - 3 } like to study? & Number & Percentage \\
\hline B.A/B.SC/B.Com & 08 & $16.00 \%$ \\
M.A/M.Sc/M.Com & 35 & $70.00 \%$ \\
MBA/MCA & 01 & $2.00 \%$ \\
PhD & 0.6 & $12.00 \%$ \\
\hline
\end{tabular}


Table 12: Education related to earning livelihood

\begin{tabular}{lll}
\hline Whether the education & \multicolumn{2}{c}{ DIET Students } \\
\cline { 2 - 3 } $\begin{array}{l}\text { received by you will helpful } \\
\text { in earning your livelihood }\end{array}$ & Number & Percentage \\
\hline Yes & 37 & $74.00 \%$ \\
No & 10 & $20.00 \%$ \\
Can't say & 03 & $6.00 \%$ \\
\hline
\end{tabular}

Table 13: Prediction on being successful in life

\begin{tabular}{lll}
\hline $\begin{array}{l}\text { Do you think students like } \\
\text { you have a good chance of } \\
\text { being successful in life? }\end{array}$ & \multicolumn{2}{c}{ DIET Students } \\
\cline { 2 - 3 } & Number & Percentage \\
\hline Yes & 35 & $70.00 \%$ \\
No & 12 & $24.00 \%$ \\
Can't say & 03 & $6.00 \%$ \\
\hline
\end{tabular}

Table 14: Method of deciding future career

\begin{tabular}{lll}
\hline How have you decided & \multicolumn{2}{c}{ DIET Students } \\
\cline { 2 - 3 } about your future career? & Number & Percentage \\
\hline I have myself decided & 15 & $30.00 \%$ \\
I have been advised by my & 00 & $0.00 \%$ \\
friends & & \\
My parents suggested me & 10 & $20.00 \%$ \\
My teacher suggested & 20 & $40.00 \%$ \\
I have not yet decided & 05 & $10.00 \%$ \\
\hline
\end{tabular}

Table 15: Satisfaction of students with facilities available in DIET, Kamki

\begin{tabular}{lll}
\hline How far you are satisfied & \multicolumn{2}{c}{ DIET Students } \\
\cline { 2 - 3 } $\begin{array}{l}\text { with the facilities provides } \\
\text { in your DIET? }\end{array}$ & Number & Percentage \\
\hline Very satisfied & 03 & $6.00 \%$ \\
Satisfied & 10 & $20.00 \%$ \\
Not satisfied & 37 & $74.00 \%$ \\
\hline
\end{tabular}

\section{Major findings of the study}

The following are the major findings of the study:

1. Only $4.00 \%$ of the DIET students had discontinued their studies where as $96.00 \%$ of them had never discontinued their studies

2. More than one fourth of students $(26.00 \%)$ remained absent very frequently and $60.00 \%$ of DIET students remained absent rarely.

3. Majority $(80.00 \%)$ of the students felt that their parents considered it necessary to educate them and only one fifth of the students felt that their parents did not allow them to become unsocial and bad citizens.
4. One-tenth of the DIET students had difficulty in understanding most of the subject taught where as $30.00 \%$ of the DIET students had difficulty in few subjects. The DIET students felt the following reasons for difficulty in understanding different subjects in order of decreasing frequency of response ( c) irregular attendance in DIET (ii) Inability of teacher to explain properly (iii) Domestic engagements (iv) lack of quiet place for studies at home (v)use of difficult language by the teacher.

5. Half of the DIET students had difficulty in studying philosophy where as $30.00 \%$ of them had difficulty in pedagogy of English.

6. $40.00 \%$ of the DIET students did not get proper study atmosphere at home.

7. More than half $(54.00 \%)$ of them received guidance occasionally whereas $40.00 \%$ of them received guidance regularly.

8. Half of the DIET students had participated frequently, $40.00 \%$ of them occasionally and only one-tenth of them had participated rarely in the co-curricular activities.

9. Majority $(74.00 \%)$ of the DIET facilities were not satisfied with the overall facilities available in DIET Kamki, whereas only $6.00 \%$ of them were very satisfied.

\section{Recommendations of the study}

On the basis of the findings of the present study, the following recommendations are made for solving the educational problems of the DIET students:

1. It was found that Only $4.00 \%$ of the DIET students had discontinued their studies where as $96.00 \%$ of them had never discontinued their studies. Half of them had discontinued their studies for either one year two years. Poor result was the main reason for discontinuance of studies of the students. Hence, it is recommended that the teachers should try to develop better attitude towards studies among the DIET students by organizing special programmes on teacher education at the DIETs, organizing seminars, workshops on teaching as a profession, by providing proper guidance and advice related to them. 
2. It was found that More than one fourth of students $(26.00 \%)$ remained absent very frequently and $60.00 \%$ of DIET students remained absent rarely. Hence, it is recommended that the teacher should take appropriate steps to motivate the students to remain present regularly in the class. They should be guided by their parents. Special orientation programmes may also be conducted by the teacher training institutions. Moreover, mass media can also be used to disseminate information pertaining to teaching as a profession.

3. It was found that One-tenth of the DIET students had difficulty in understanding most of the subject taught where as $30.00 \%$ of the DIET students had difficulty in few subjects. The DIET students felt the following reasons for difficulty in understanding different subjects in order of decreasing frequency of response (i) irregular attendance in DIET (ii) Inability of teacher to explain properly (iii) Domestic engagements (iv) lack of quiet place for studies at home (v)use of difficult language by the teacher. Hence it is recommended that the parents and teachers of the DIET students should make extra efforts to make the students understand the subjects being taught. They should use simple and clear language while explain difficult concepts.

4. It was found that $40.00 \%$ of the DIET students did not get proper study atmosphere at home. Hence it is recommended that the parents of the tribal students should provide proper study atmosphere to their children and they should inspire their children to devote and concentrate more time to their studies.

5. It was found that Majority $(74.00 \%)$ of the DIET facilities were not satisfied with the overall facilities available in DIET Kamki, whereas only $6.00 \%$ of them were very satisfied.. Hence it is recommended that the Head of the institution /authorities should provide necessary facilities to the students. Besides, the State Government and the administrative officers should make adequate funding provisions and supply necessary materials required for carrying out of curricular, co-curricular and extra curricular activities of the DIET.

\section{CONCLUSION}

In conclusion, it can be said that teaching profession is one of the oldest and noblest professions of the world. Teaching profession requires skillful, competent and effective teachers who are the nation builders and who shape the future destiny of a nation. Attitude towards teaching profession in the present day life is poor and negative. Students after having good academic credentials pursue other professions sidelining teaching profession as their career. Educational Problems of students especially at teacher training level is very important to consider and teachers have to take appropriate steps in this regard. However, in recent times both at the public and private level this notion has been changed because of the change in government's perception of teaching as a profession. The findings, recommendations and implications of the present study will help the administrators, bureaucrats and academicians to undertake appropriate measures for developing positive attitude towards teaching profession.

\section{REFERENCES:}

Aggarwal, J.C. 2014. Educational Technology, Shipra Publications, New Delhi.

Bhattanagar, A.B et al. 2005. Advanced Educational Technology, Surjeet Publications, Meerut.

Kochhar, S.K. 2004. Methods and Techniques of Teaching, Vikas Publishing House, New Delhi.

Mathur, S.S. 2004. A Sociological Approach to Indian Education, Vinod Pustak Mandir, Agra.

Mangal, S.K. and Mangal, Uma. 2014. Advanced Educational Technology, Prentice Hall if India, New Delhi.

Pandey, R.S. 2008. Principles of Education, Aggarwal Publications, Agra.

Pradhan, S.K. 2013. Text Book on Elements of Education, DKD Publishers, Aalo, 2013

Pradhan, S.K. 2015. Text Book on Indian Education and its Problems, Lucky Publishers, Bhubaneswar.

Pradhan, S.K. 2015. Text Book on Foundations of Education, Lucky Publishers, Bhubaneswar.

Saxena, N.R.S. 2010. Technology of Teaching, R.Lall Book Depot, Meerut.

Taneja, V.R. 2000. Educational Thought and Practice, Sterling Publisgers Pvt, Ltd, New Delhi.

Vanaja, M. 2010. Educational Technology, Neelkamal Publications Pvt Ltd., Hyderabad. 
